Wang, H., Byrne, J., Perez, J., Thomas, A., Göttlicher, J., Höfer, H., Mayanna, S., Kontny, A., Kappler, A., Guo, H., Benning, L. G., Norra, S. (2020): Arsenic sequestration in pyrite and greigite in the buried peat of As-contaminated aquifers. - Geochimica et Cosmochimica Acta, 284, 107-119.

https://doi.org/10.1016/j.gca.2020.06.021 


\section{Arsenic sequestration in pyrite and greigite in the buried peat of As-contaminated aquifers}

2 H.Y. Wang ${ }^{a^{*}}$, J.M. Byrne ${ }^{\text {b }}$, J.P.H. Perez, ${ }^{\text {,d }}$, A.N. Thomas ${ }^{a}$, J. Göttlicher ${ }^{\mathrm{e}}$, H.E. Höfer ${ }^{\mathrm{f}}$, S. Mayanna ${ }^{\mathrm{c}}$, 3 A. Kontny ${ }^{\mathrm{a}}$, A. Kappler ${ }^{\mathrm{b}}$, H.M. Guo ${ }^{\mathrm{g}}$, L.G. Benning ${ }^{\mathrm{c}, \mathrm{d}}$, S. Norra ${ }^{\mathrm{a}}$

4 anstitute of Applied Geoscience, Working Group of Environmental Mineralogy and 5 Environmental System Analysis, Karlsruhe Institute of Technology (KIT), 76131 Karlsruhe, 6 Germany

7 beomicrobiology, Center for Applied Geosciences, University of Tuebingen, 72074 Tuebingen, 8 Germany

$9 \quad{ }^{\mathrm{c}}$ GFZ German Research Center for Geoscience, 14473 Potsdam, Germany

10 dDepartment of Earth Sciences, Freie Universität Berlin, 12249 Berlin, Germany

11 Institute of Synchrotron Radiation, Karlsruhe Institute of Technology (KIT), 76131 Karlsruhe, 12 Germany

13 Institute of Geoscience, Goethe University, 60438 Frankfurt, Germany

14 gState key Laboratory of Biogeology and Environmental Geology, China University of Geoscience, 15100083 Beijing, China 


\section{Abstract}

Detrital peat (organic carbon-enriched deposit) with high arsenic (As) content is widely distributed in sediments where groundwater As contamination exists. Iron sulfides often persist in these sediments under anoxic conditions. However, the mechanisms and pathways of formation of iron sulfides and its potential contribution in controlling As mobility are still poorly understood. In this study, we examined three As-contaminated peat sediments from the Hetao Basin in China to gain better understanding of the complex interplay between iron sulfides formation and As mobility. We employed high-resolution spectroscopic techniques, including X-ray absorption spectroscopy and ${ }^{57} \mathrm{Fe}$ Mössbauer spectroscopy, coupled with electron microscopy to determine the speciation of iron sulfides and the associated As in the peat sediments.

Pyrite $\left(\mathrm{FeS}_{2}\right)$ and metastable greigite $\left(\mathrm{Fe}_{3} \mathrm{~S}_{4}\right)$ persisted in peat as end-members of $\mathrm{S}$ and $\mathrm{Fe}$ diagenetic pathways. The Fe-rich phyllosilicates and decaying plant tissues provided the ideal micro-environments for pyrite and greigite nucleation. Pyrite formation most likely occurred via the polysulfides pathway in the surface water-sediments interface during early diagenetic process, while the relative enrichment of reactive Fe compared to sulfide possibly inhibited the transformation of greigite to pyrite in such Fe-rich sediments.

Our results revealed that the peat sediments could act as a stable sink for As immobilization under steady groundwater anoxic conditions, with As content up to $250 \mathrm{mg} / \mathrm{kg}$ and large proportions (40 to $60 \mathrm{wt} . \%$ As) sequestered in pyrite and greigite. Pyrite crystallites had up to $1 \mathrm{wt} . \%$ As content through the replacement of the $\mathrm{S}^{-\mathrm{I}}$ sites. Greigite crystallites had a relatively constant As content ranging from $\sim 500$ to $\sim 1,400 \mathrm{mg} / \mathrm{kg}$. Instead of being adsorbed or structurally incorporated, arsenic formed distinct arsenic sulfide phase in the greigite-enriched sediments, which was analogous to realgar. The transfer of As from iron sulfides to ferrihydrite temporarily retarded As release into 
40 groundwater under slightly oxic groundwater conditions. However, the reductive dissolution of

41 ferrihydrite and potential subsequent As re-release could be a source of As in groundwater under

42 disturbed redox conditions.

43 Keywords: peat; arsenic; greigite; pyrite; sediment biogeochemistry; early diagenesis 
45 Over a hundred million people are exposed to groundwater with high levels of arsenic (As) (> 10 $46 \mu \mathrm{g} / \mathrm{L})$ globally, particularly in South and Southeast Asia including the Ganges-Brahmaputra47 Megha, Red River and Mekong Deltas and the basins belong to the Yangtze and Yellow River 48 catchments (Winkel et al., 2008; Fendorf et al., 2010; Wang et al., 2019 b). It is widely accepted 49 that microbial reduction of Fe (oxyhydr)oxides coupled to organic carbon oxidation causes the 50

51 Guo et al., 2013). The reactivity and availability of organic matter, partitioning of As in solids and 52 the presence of other redox-active species (e.g., $\mathrm{NO}_{3}{ }^{-}, \mathrm{SO}_{4}{ }^{2-}$ ) largely influence As speciation and 53 partitioning between groundwater and solid phases (O’Day et al., 2004 b; Langner et al., 2012; 54 Stuckey et al., 2015 a; Zhu et al., 2017; Smith et al., 2017).

55 Peat is a heterogeneous mixture of (partly) decayed plant materials that accumulate anaerobically 56 (Naafs et al., 2019). Abundant reactive organic matter provides electrons for the reductive 57 transformation of $\mathrm{Fe}$ (oxyhydr)oxides, thereby influencing the behavior of trace elements that are peat for As mobilization has been extensively discussed in terms of reductive dissolution of Fe(III)

62 (oxyhydr)oxides. On one hand, dissolved organic matter degraded from plants in the peat lenses can be transported to different locations by groundwater flow, stimulate microbial reduction of

$64 \mathrm{Fe}(\mathrm{III})$ (oxyhydr)oxides and $\mathrm{As}(\mathrm{V})$ reduction and thereby releasing arsenic into groundwater 65 (McArthur et al. 2001, 2004; Anawar et al. 2003; Fendorf et al., 2010). On the other hand, the 66 detrital peat buried in the sediments can serve as a special sink for As. Following the reductive 
67 dissolution of $\mathrm{Fe}(\mathrm{III})$ (oxyhydr)oxides and $\mathrm{As}(\mathrm{V})$ species, mobilized As(III) species can be

68 subsequently sequestrated by sulfides, with sulfide arising from reduced organic sulfide in peat or

69 microbial reduction of $\mathrm{SO}_{4}{ }^{2-}$ (Stuckey et al., 2015 b; Wang et al., 2018; Knappová et al., 2019).

70 Furthermore, recent research shows that reactive organic thiol groups formed by incorporating

71 inorganic sulfide into organic carbon can adsorb As in contaminated peatlands, providing another

72 sink for As (Langner et al., 2012, 2013; Wang et al., 2018). Therefore, the influence of peat for As

73 behavior is complex and affected by Fe-C-S coupled mineralization pathways. Understanding the

74 diagenetic process in the peat layers and related As speciation are vital to gain better understanding

75 on the influence of peat sediments in As immobilization in contaminated anoxic environments.

76 Arsenic-Fe sulfides associations are common features in peat layers, and act an important role for

77 As immobilization. Iron sulfides found in the natural sediments mainly include mackinawite

78 (nominally "FeS"), greigite and pyrite (Wilkin and Ford, 2006; Pickard et al., 2017; Knappová et

79 al., 2019). Recent research suggests that Fe sulfides are main As carriers in the detrital peat of As

80 contaminated aquifer in South and Southeast of Asia. For example, arsenic is mainly sequestrated

81 in pyrite found in peat from Mekong River Delta and Bangladesh (Lowers et al., 2007; Stuckey et

82 al., 2015 b; Wang et al., 2018). Several studies have been conducted to study the mechanisms of

83 Fe sulfides formation as well as the adsorption/incorporation behavior of As in the laboratory scale

84 (Benning et al., 2000; Bostick and Fendorf, 2003; Blanchard et al., 2007; Kirk et al., 2010; Le et

85 al., 2017). However, the diagenetic formation process in natural settings and

86 adsorption/incorporation mechanisms for As are still not sufficiently understood because Fe

87 sulfides and related As species are difficult to characterize and quantify due to its oxygen-sensitive

88 nature and poorly crystalline properties. 
89 Based on the assumption that diagenetic process especially Fe sulfides formation in the peat can

90 influence As partitioning in sediments and groundwater, we separated three peat lenses from the

91 sediments of Hetao Basin, an important inland basin draining Yellow river with As contaminated

92 groundwater. Using these, we seek to (1) define the $\mathrm{S}$ and Fe diagenetic minerals in peat lenses,

93 (2) investigate As speciation in both peat sediments and specific Fe sulfides, and (3) evaluate the

94 potential role of peat layers in controlling the toxicity and mobility of As in aquifers. The buried

95 peat in the Hetao Basin formed either by over-flowed flood debris or swamps is analogous to other

96 peat formed in As contaminated aquifers in South and Southeast Asia, therefore the research results

97 can be applicable to comparable subsurface environments.

\section{2. Material and Methods}

\subsection{Field area}

The Hetao Basin is a typical inland basin lying in the central part of Inner Mongolia (China) with

101 the Lang Mountains in the North and the Yellow River in the South, covering an area of about $10213,000 \mathrm{~km}^{2}$. In the early time of late Pleistocene ( 120 ka) epoch, the Yellow River began to flow 103 through the Hetao paleolake. At the same time, the paleolake started to shrink due to the cooling 104 climate (Jia et al., 2016). Salt marshes as well as oxbow lakes were generated as a result of 105 paleolake shrinkage and frequent movement of the Yellow River channels (Cai et al., 2019), 106 resulting in the accumulation of organic matter. The study site was located in the flat plain of 107 northwestern Hetao Basin which was one of most As contaminated area. The stratigraphy of the 108 late Pleistocene and the Holocene covered a depth around $150 \mathrm{~m}$, whereas the Holocene sediments 109 primarily included alluvial-fluvial sediments with thicknesses of $\sim 10 \mathrm{~m}$ (Deng et al., 2009). Further 110 detailed information about the study area such as hydrological conditions were outlined in a 111 previous study (Zhang et al., 2020). 


\section{$112 \quad$ 2.2 Sediments collection, bulk geochemistry composition and mineral phase analysis}

113 Two multilevel wells, K1 $\left(41^{\circ} 0^{\prime} 9.00^{\prime \prime} \mathrm{N}, 106^{\circ} 57^{\prime} 59.20^{\prime \prime} \mathrm{E}\right)$ and $\mathrm{K} 2 \quad\left(41^{\circ} 1^{\prime} 2.10^{\prime \prime} \mathrm{N}\right.$,

$\left.114106^{\circ} 57^{\prime} 24.50^{\prime \prime} \mathrm{E}\right)$, were selected in the study area. The wells were drilled in October 2015 by the

115 China University of Geosciences (Beijing) (CUGB) using a circulatory drilling method. After

116 bringing the cores to the surface, they were split into $10 \mathrm{~cm}$ sections according to lithology and

117 color variations observed visually, and then capped and placed into $\mathrm{N}_{2}$-purged Mylar bags. More

118 detailed information about well construction and sediments sampling information has been

119 reported by Zhang et al. (2020). Groundwater samples from different depths (sampling length: 1

$120 \mathrm{~m})$ were collected after the wells were constructed and then analyzed at CUGB. The geochemical

121 and mineralogical composition of the sediments were analyzed at the Karlsruhe Institute of 122 Technology (KIT). Methods for the groundwater sampling, geochemical analysis, and

123 determination of elemental and organic carbon content and isotopic composition are detailed in

124 the supplementary information (Supplementary text 1). Methods for mineralogical

125 characterization of magnetically separated minerals, and sequential extractions of Fe-bearing

126 phases in the bulk sediments are shown in the supplementary information (Supplementary text 2

127 and Supplementary Table S1). The magnetic susceptibility measurements of the peat sediments 128 are described in detail in Supplementary text 3. 
K1
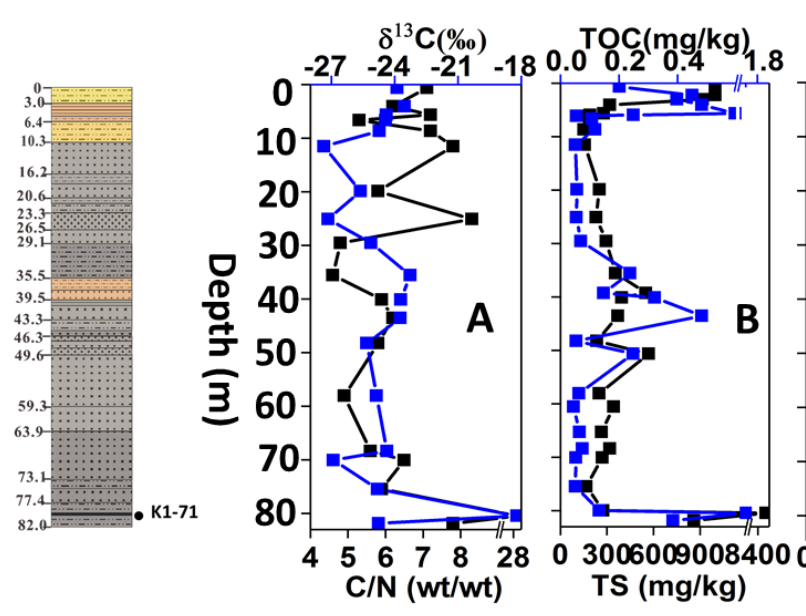

$\mathrm{Fe}(\mathrm{wt} \%)$

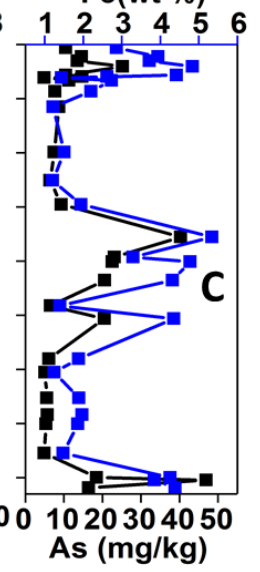

GR ORP (mV)

$\begin{array}{rlll}-160-80 & 0 & 80\end{array}$
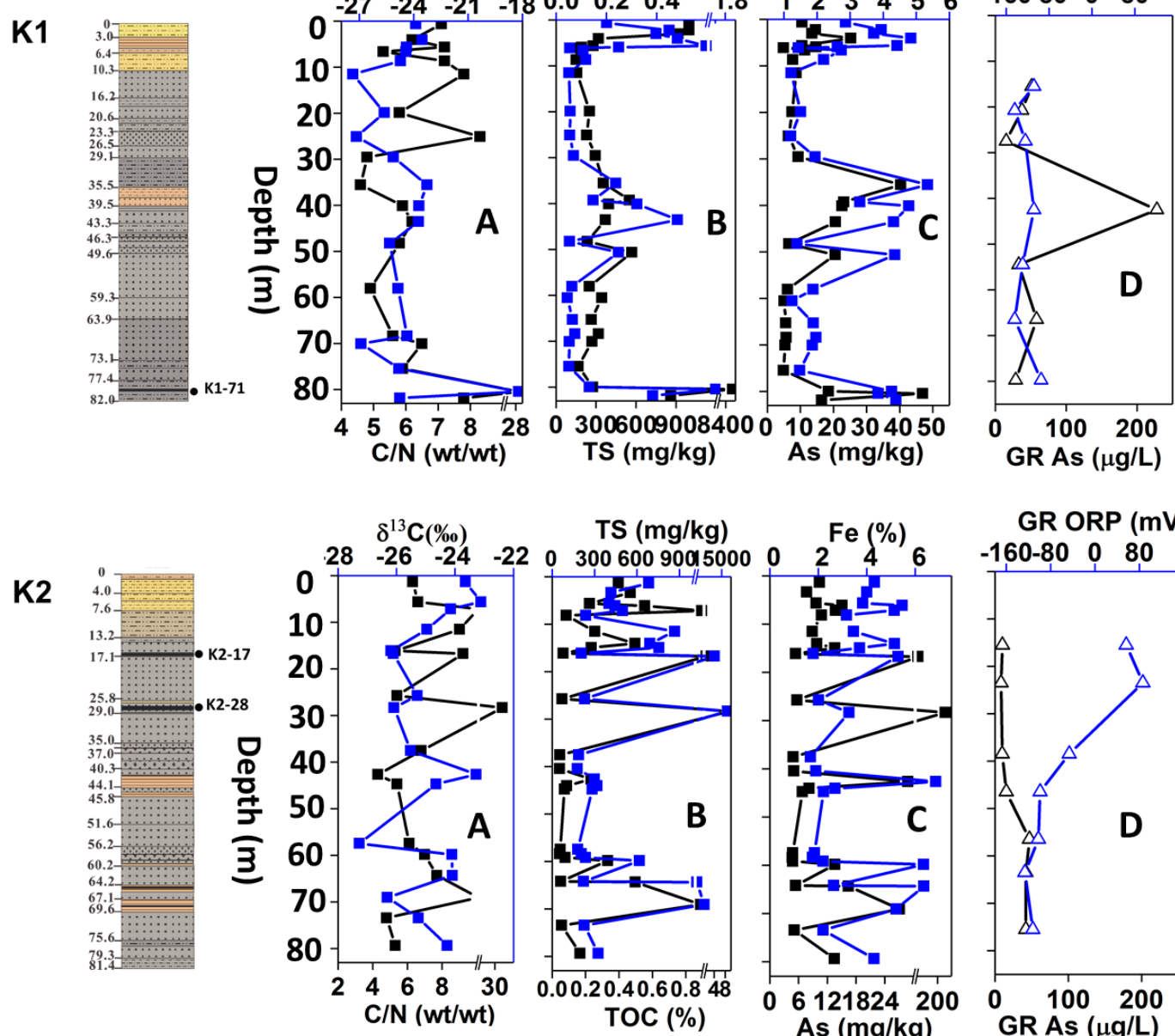

Fig. 1 Lithology and elemental content in the sediments profiles as well as groundwater redox conditions and As concentrations from different depths: (A) Isotope signature of organic carbon

$132\left(\delta^{13} \mathrm{Corg}\right.$, blue $)$ and ratio of organic carbon to total nitrogen $(\mathrm{C} / \mathrm{N}$, black); (B) total sulfur content

133 (TS, blue) and total organic carbon (TOC, black); (C) total Fe (blue) and As content (black); and

134 (D) groundwater redox conditions (GW ORP, blue) and As concentrations (black). Drawing color of the cores represents the visualized sediments colors, layers labeled with black dots (K1-71, K217, and K2-28) represent the analyzed peat sediments.

\section{$2.3^{57} \mathrm{Fe}$ Mössbauer analysis}


138 A section of peat was separated from each intact core for Mössbauer analysis at the University of

139 Tübingen. Inside the glovebox (pure nitrogen atmosphere), dried powders of peat samples were

140 loaded into Plexiglas holders (area $1 \mathrm{~cm}^{2}$ ), forming a thin disc. Samples were kept in airtight jars

141 under anoxic conditions at $-20{ }^{\circ} \mathrm{C}$ until measurement. Holders were inserted into a closed-cycle

142 exchange gas cryostat (Janis cryogenics) under a backflow of He to minimize exposure to air.

143 Spectra were collected at $20 \mathrm{~K}$ using a constant acceleration drive system (WissEL) in transmission

144 mode with a ${ }^{57} \mathrm{Co} / \mathrm{Rh}$ source. All spectra were calibrated against a $7-\mu \mathrm{m}$ thick $\alpha-{ }^{57} \mathrm{Fe}$ foil that was

145 measured at room temperature. Analysis was carried out using Recoil (University of Ottawa) and

146 the Voigt Based Fitting (VBF) routine (Rancourt and Ping, 1991). The half width at half maximum

147 (HWHM) was constrained to $0.13 \mathrm{~mm} / \mathrm{s}$ during fitting.

\subsection{Scanning Electron Microscopy (SEM) and Electron probe microanalysis (EPMA)}

149 Thin sections for SEM imaging and EPMA analysis were prepared at KIT. A section of peat was 150 separated from intact cores, and embedded in an arsenic free-resin in the glovebox after drying 151 (Araldite, 2020). Sections of 1-mm thickness were cut and polished down to a thickness of $80 \mu \mathrm{m}$.

152 Thin sections were stored in the glovebox until analysis.

153 Carbon-coated thin sections were used for SEM imaging and EPMA analysis. SEM images were 154 acquired at the GFZ German Research Center for Geosciences using a Zeiss Ultra Plus FE-SEM 155 at an acceleration voltage of $3 \mathrm{kV}$ with10 $\mu \mathrm{m}$ aperture distance using an In-lens secondary electron 156 detector. Following mineral observations using SEM, selected particles and areas were analyzed 157 at Goethe University by wavelength spectrometer electron probe microanalysis (EPMA, JEOL 158 8900). The operating conditions were $20 \mathrm{keV}$ accelerating voltage and $20 \mathrm{nA}$ beam current. Iron, $159 \mathrm{~S}, \mathrm{Si}, \mathrm{Ca}, \mathrm{Mg}$ and As concentrations were quantified using peak counting times of $10 \mathrm{~s}$ for Fe, S, $160 \mathrm{Si}, \mathrm{Ca}, \mathrm{Mg}$, and $60 \mathrm{~s}$ for As. The detection limit for As was about $90 \mathrm{mg} / \mathrm{kg}$. For As, S and Fe 
161 mapping, pixel size was set to $0.1 \mu \mathrm{m} \times 0.1 \mu \mathrm{m}$. The analysis volume for particles was 162 approximately $0.2 \mu \mathrm{m}-0.3 \mu \mathrm{m}$ based on the Monte Carlo simulations.

\subsection{As, S and Fe K-edge X-ray absorption spectroscopic analysis}

164 The speciation and local bonding environment of As, S and Fe in selected peat samples were 165 characterized using X-ray absorption spectroscopy (XAS) analysis at the SUL-X beamline at the 166 ANKA synchrotron radiation facility (KIT). Samples were collected from each peat and ground 167 into powder after drying in the glovebox. A sample mass for Fe K-edge XAS analysis was 168 calculated by the program XAFSmass and mixed with boron nitride (Sigma-Aldrich) prior to 169 analysis (Klementiev, 2012). For As and Fe K-edge XAS analysis, powdered samples were 170 suspended in deoxygenated water in the glovebox, drop-casted onto Kapton tape, and sealed using

171 a second piece of Kapton tape. Arsenic K-edge EXAFS spectra for sample K2-28 was analyzed at 172 the BM23 beamline of the European Synchrotron Radiation Facility (ESRF, Grenoble, France) 173 using the same sample preparation method. For S K-edge XAS measurements, dried peat samples 174 were directly loaded onto the Kapton tape surface. Three scans to 12 scans were collected per 175 sample for each As, Fe and S K-edge XAS spectrum. Data reduction and analysis of XAS spectra 176 were performed using Athena software package (Ravel and Newville, 2005). Experimental and 177 data analysis procedures can be found in the supplementary information (Supplementary text 4).

\section{3. Results}

\subsection{Geochemical composition of peat sediments}

180 Surface sediments $(\sim 10 \mathrm{~m})$ from cores $\mathrm{K} 1$ and $\mathrm{K} 2$ were yellowish to brownish in color and fine-

181 grained with a silt/clay like texture, whereas gray aquifer sediments with interbedded brown/gray 182 clay lenses were found at a depth of $\sim 10 \mathrm{~m} \mathrm{(K1)}$ and $\sim 14 \mathrm{~m}(\mathrm{~K} 2)$ to $82 \mathrm{~m}$ (maximum sampled 
183 depth) (Fig. 1). In borehole K1, a $\sim 5 \mathrm{~cm}$ thick black peat band located between 80.4 and $80.5 \mathrm{~m}$

184 (K1-71) was composed of a poorly sorted mixture of fine sand, clay and small amounts of medium

185 sand. In borehole $\mathrm{K} 2$, a $\sim 5 \mathrm{~cm}$ poorly sorted clay peat band was found at a depth of $16.7-16.8 \mathrm{~m}$

186 (K2-17), and a peat layer composed of fine sand and visible detrital plant materials with thickness

187 of at least of $10 \mathrm{~cm}$ was observed at a depth of $28.3-28.4 \mathrm{~m}(\mathrm{~K} 2-28)$.

188 Arsenic content in the sediments was found to be between $4.7 \mathrm{mg} / \mathrm{kg}$ to $40.3 \mathrm{mg} / \mathrm{kg}$ (except for the

189 peat layers) with generally higher content found in clay sediments (Table 1). Meanwhile, clay

190 sediments had slightly higher Fe content (3.94\% in average) than silt (2.86\% in average) and sand

191 (1.46\% in average) (Table 1). Peat sediments showed significantly higher total organic carbon

192 (TOC) and total sulfur (TS) content, and $\mathrm{C} / \mathrm{N}$ ratios than in the underlying and overlying sediments

193 (Fig. 1 and Table 1). Much higher As content was found in the peat lenses (up to $\sim 250 \mathrm{mg} / \mathrm{kg}$ )

194 in comparison with other sediments (Fig. 1 and Table 1). In comparison with peats K1-71 and

195 K2-17, peat K2-28 had much higher organic matter as well as total S content (Table 1).

196 Table 1 Geochemical compositions of studied peat sediments and comparison with other 197 sediments.

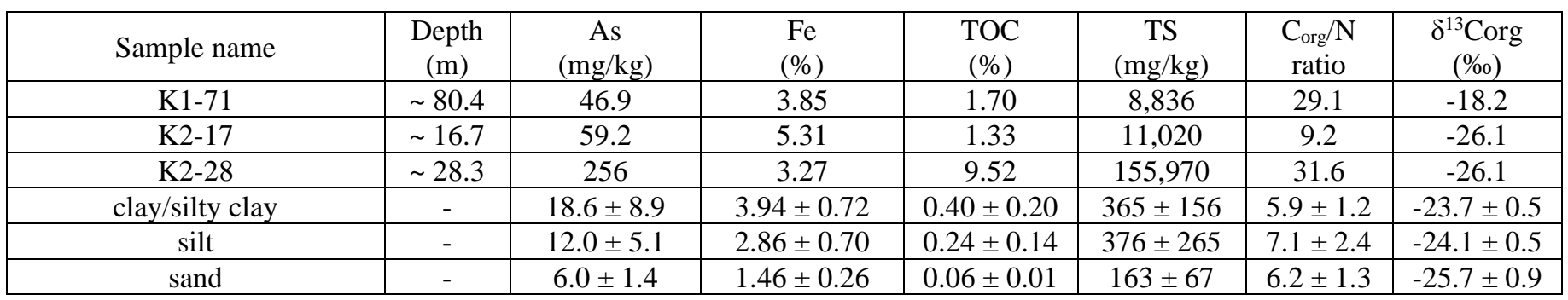


The pre-edge inflection point near $7112 \mathrm{eV}$ and primary inflection point near $7119 \mathrm{eV}$ in the first derivative Fe K-edge XANES spectra suggested that Fe sulfides were abundant in the peat lenses

204 (Supplementary Fig. S3) (O’Day et al., 2004 a). The results of Fe K-edge extended X-ray 205 absorption fine structure (EXAFS) linear combination fitting (LCF) revealed that, aside from phyllosilicates $(\sim 53 \%$ and $\sim 66 \%)$, greigite $(\sim 23 \%$ and $\sim 42 \%)$ was the primary Fe-bearing mineral phase in K2-17 and K1-71, respectively. Meanwhile, pyrite $(\sim 22 \%)$ and ferrihydrite $(\sim 17 \%)$ in combination with phyllosilicates $(\sim 59 \%)$ were the dominant Fe-bearing phases in K2-28 (Fig. 2 a and Table 2).

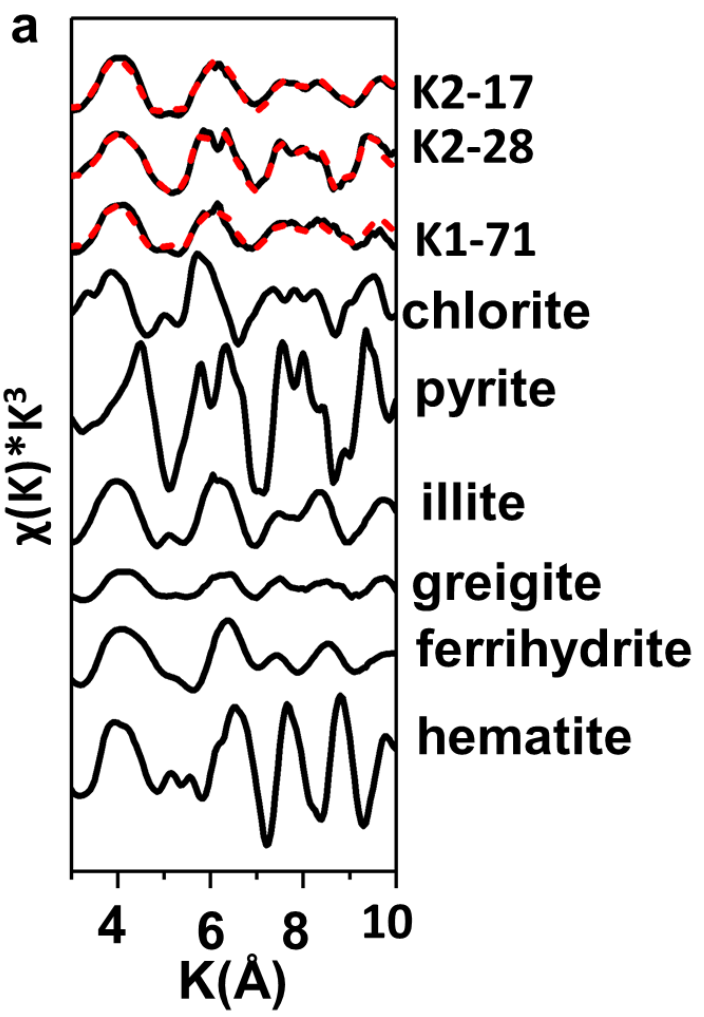

Fig. 2 (a) LCF fitting results of Fe K-edge EXAFS. Black lines represent experimental data for samples and model compound spectra used for fitting, and red dashed lines represent LCF fits. (b) 
$213{ }^{57} \mathrm{Fe}$ Mössbauer spectra collected at $20 \mathrm{~K}$ for peat sediments, ph: phyllosilicates; py: pyrite; M:

214 mackinawite.

$215 \quad{ }^{57} \mathrm{Fe}$ Mössbauer spectroscopy was used to identify Fe-bearing mineral phases as a complementary 216 technique to synchrotron-based Fe K-edge EXAFS (Fig. 2 b). The parameters of the narrow sextet 217 in the peat samples K2-17 and K1-71 were typical of greigite (magnetic hyperfine field of 31.2 T 218 and $32.0 \mathrm{~T}$, isomer shift: 0.59 and 0.57 , quadrupole shift of 0.00 and -0.04) (Vandenberghe et al., 219 1992), comprising $\sim 27 \%$ and $\sim 30 \%$ of the Fe phases, respectively (Supplementary Table S6). 220 Differences less than $10 \%$ in the greigite component between the Fe K-edge EXAFS and 221 Mössbauer spectroscopy fits in peat sediments K2-17 and K1-71 is considered to be acceptable 222 (Thomas-Arrigo et al., 2014; Chen et al., 2017).

223 Unfortunately, the similarity of phyllosilicates Fe(III) and pyritic Fe(II) in the Mössbauer spectra 224 at $20 \mathrm{~K}$ can result to misidentification of pyrite in peat samples K2-17 and K2-28. However, the 225 Fe K-edge EXAFS spectra of pyrite and phyllosilicates can be easily distinguished (O'Day et al., 2262004 a), and these fitting results matched the Mössbauer spectroscopy fits (Table 2 and 227 Supplementary Table S6). Furthermore, an expected ferrihydrite sextet in the 20 K Mössbauer 228 spectra was not observed, even in sample K2-28, while Fe (oxyhydr)oxides were detected by Fe 229 K-edge EXAFS. The magnetic ordering temperature of ferrihydrite is strongly dependent on the 230 mineral purity, crystallite size and crystallinity, and as such the absence of a ferrihydrite sextet in 231 the Mössbauer spectra does not necessarily mean that it is absent, as shown using other 232 spectroscopic measurements (Wang et al., 2016). The presence of ferrihydrite in the K2-28 peat 233 sample was further confirmed by measurements of magnetic susceptibility, which decreased in 234 value from $-192{ }^{\circ} \mathrm{C}$ to $0{ }^{\circ} \mathrm{C}$ (Supplementary Fig. S2) (Pannalal et al., 2005).

\subsubsection{Texture and morphologies of Fe-bearing phases (SEM-EDX analysis)}


236 The Fe-bearing minerals texture and morphologies were evaluated according to SEM-EDX

237 analysis based on the known minerals which were obtained by Fe K-edge XAS and Fe Mössbauer

238 analysis.

239 Greigite aggregates nucleated in detrital silicates and decaying plant tissues, and less in

240 gypsum/anhydrite (Fig. 3). The grain size ranged from $\sim 80 \mathrm{~nm}$ to $\sim 500 \mathrm{~nm}$, whereas diverse

241 crystallite habits were observed, including cuboidal, prismatic, and elongated particles.

242 Neoformation of pyrite was also primarily occurred in confined spaces including plant tissues,

243 phyllosilicates grains. The diameters of framboidal pyrites ranged from $\sim 5 \mu \mathrm{m}$ to $\sim 40 \mu \mathrm{m}($ Fig. 3).

244 Framboidal crystallites showed either octahedral, cubic ( $2 \mu \mathrm{m}$ in diameter) or spherical crystal

245 habits $(\sim 1 \mu \mathrm{m}$ in diameter). Massive pyrite crystals occurred with octahedral, cubic or irregular 246 habits, with diameters up to $\sim 10 \mu \mathrm{m}$. Ferrihydrite was found to be associated with pyrite particles.
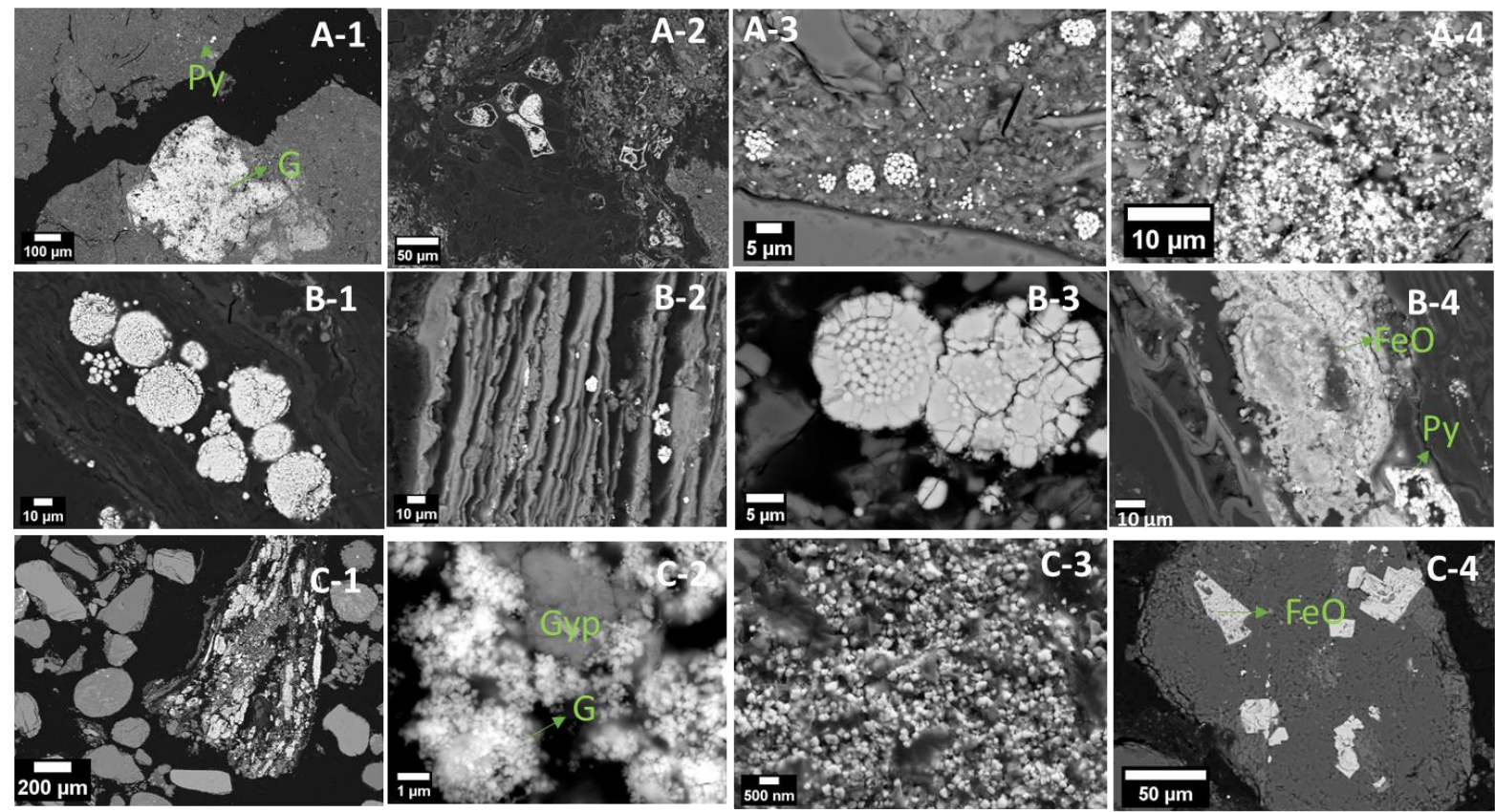
249 Fig. 3 Representative images of peat samples (A) K2-17, (B) K2-28 and (C) K1-71. (A-1) 250 Representative greigite $(\mathrm{G})$ and framboidal pyrite (Py) areas as indicated. (A-2) Greigite/pyrites 251 nucleation in plant cells. (A-3) and (A-4) Nucleation of pyrites/greigite in phyllosilicates. (B-1) 252 Framboidal and massive pyrites nucleation in plant tissues. (B-2) Massive pyrites nucleation in the 253 phyllosilicates. (B-3) Framboidal pyrites nucleation in phyllosilicates. Overgrowth rims and 254 interior crystallites were visible. (B-4) Mixture of ferrihydrite and pyrites in plant tissues/cells. (C255 1) Greigite nucleation in phyllosilicates. (C-2) Greigite (G) nucleation in gypsum/anhydrite (Gyp). 256 (C-3) Scattered electron images to show greigite grains. (C-4) Clastic iron oxides (FeO) in the 257 sediment matrix.

\section{$258 \quad 3.3$ Sulfur speciation in the peat sediments}

259 Sulfur speciation in the peat sediments was analyzed by S K-edge XANES spectra. Based on the 260 primary white line positions, the presence of reduced organosulfur species can be ruled out since 261 they often have white line positions at > $2472 \mathrm{eV}$ (Manceau and Nagy, 2012). The primary 262 inflection points at $\sim 2469.1 \mathrm{eV}$ and $\sim 2471.1 \mathrm{eV}$ in $\mathrm{K} 2-17$ and $\sim 2469.1 \mathrm{eV}$ in $\mathrm{K} 1-71$ revealed that 263 inorganic sulfides were the primary sulfur-bearing phases, whereas the pronounced inflection 264 points of $\sim 2471.2 \mathrm{eV}$ and $\sim 2481.6 \mathrm{eV}$ in peat sample K2-28 corresponded to inorganic sulfides 265 and $\mathrm{SO}_{4}{ }^{2-}$ from evaporites, respectively (Fig. 4). Iron monosulfide minerals (FeS) were not used 266 in the XANES and XANES first derivative LCF fitting because their characteristic features were 267 not observed in either Fe K-edge XAS analysis or sequential experiments (Fig.2 a and 268 Supplementary Table S2). Sulfur K-edge first derivative XANES LCF fitting showed that $S^{2-}$ is 269 the dominant S-bearing phase in K1-71 ( 93\%) and K2-17 ( 70\%). In sample K2-28, 30\% and $270 \sim 60 \%$ of $S$ was in the form of $S^{-1}$ and zero-valent sulfur $\left(S_{0}\right)$, respectively (Fig. 4 and Table 2). 

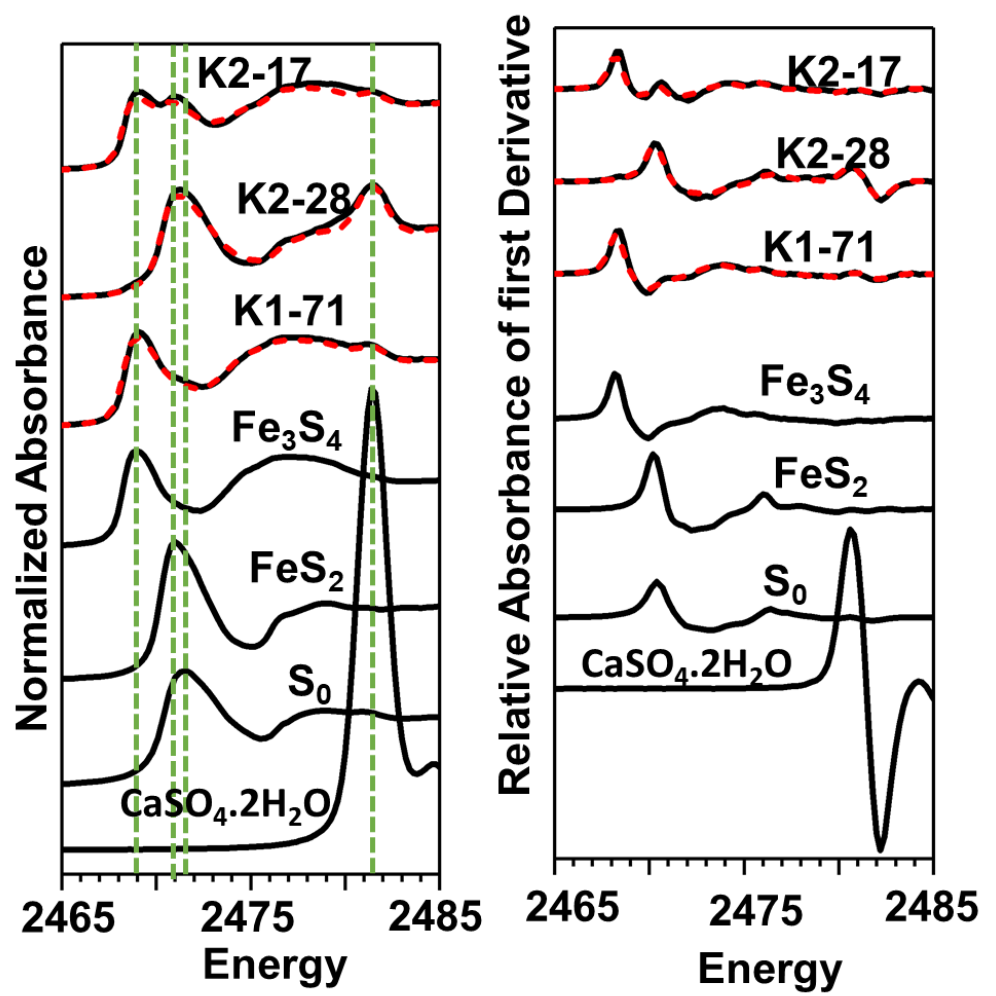

272 Fig. 4 Results of LCF fitting for S K-edge XANES and first derivative K-edge XANES spectra.

273 Black lines represent experimental data, whereas red dashed lines represent the fits. Green dashed

274 lines represent inflection points of selected model compounds.

\subsection{Arsenic speciation and distribution in the peat sediments}

\subsubsection{As K-edge XAS analysis}

277 The peat sediments of K1-71 and K2-17 both had white line energies near $11870 \mathrm{eV}$, which most

278 likely indicates As(III) species were coordinated by sulfide (Smith et al., 2005). Arsenian

279 pyrite/arsenopyrite detected in sample K2-17 do not seem to be major sinks for As due to the 280 absence of the associated white line at $\sim 11867.6 \mathrm{eV}$ and the minimal pyrite content $(<5 \%)($ Fig.

2815 A and Table 2). The first shells of the Fourier-transformed EXAFS spectra of K2-17 and K128271 were comparable with the As(III)-O bond distance $(\sim 1.7 \AA)$, while the second shell was 283 consistent with the As(III)-S bond distance ( 2.3 $)$ ) (Bostick and Fendorf, 2003) (Fig. 5 D). First 
derivative K-edge XANES LCF fitting shows that $\sim 40 \%$ of As is in the form of As-sulfide compounds in K2-17 and K1-71 while around 50\% of As is in the form of arsenite (Table 2).

In peat K2-28, two inflection points occurred at $\sim 11868 \mathrm{eV}$ and $\sim 11874 \mathrm{eV}$ (Fig. 5 A), suggesting that the sample was mainly composed of arsenopyrite/arsenian pyrite $(\sim 11868 \mathrm{eV})$ and arsenate $(\sim 11874 \mathrm{eV})$. First derivative As K-edge XANES LCF fitting showed that $\sim 61 \%$ and $\sim 27 \%$ of As was presented as arsenopyrite/arsenian pyrite and As(V) species, respectively (Table 2).
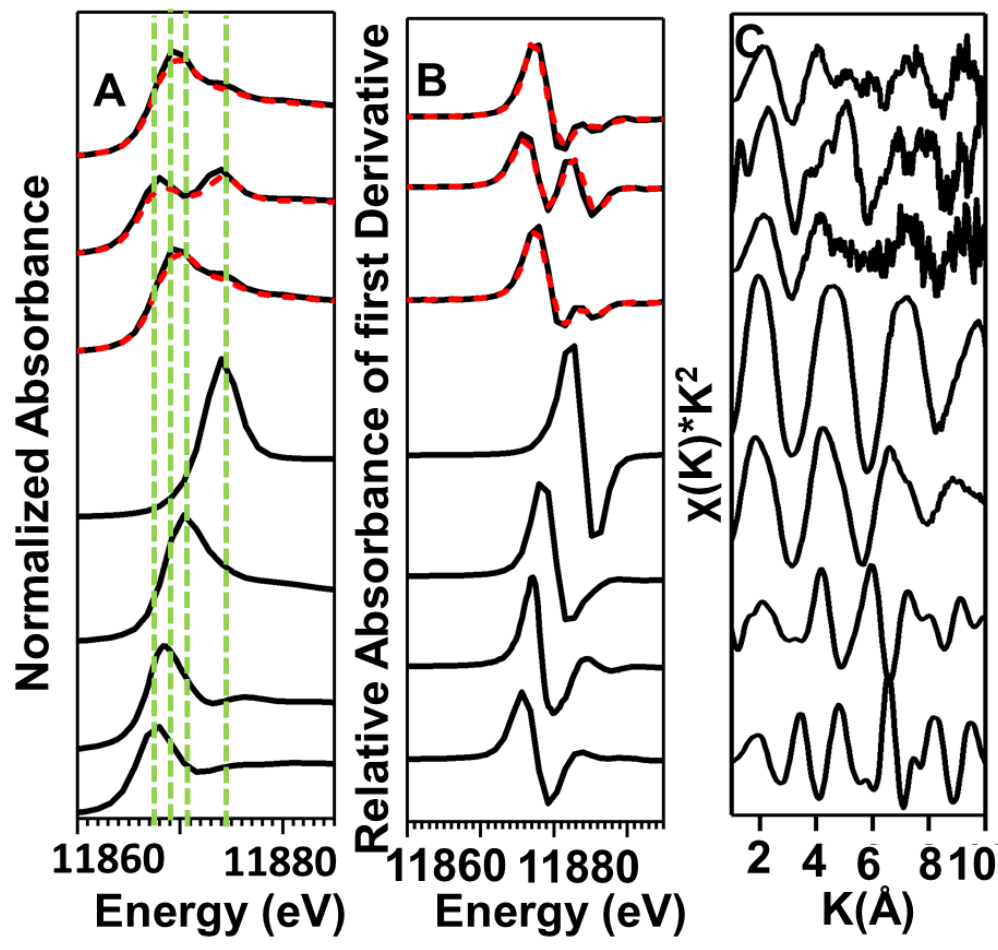

290

Fig. 5 As K-edge (A) XANES and (B) first-derivative XANES spectra of peat sediments and 292 selected model compounds. The red dashed lines represent fits and the green dashed lines represent inflection points of selected model compounds (i.e., As(III)/As(V) adsorbed onto ferrihydrite, realgar $\left(\mathrm{As}_{4} \mathrm{~S}_{4}\right)$, arsenopyrite). (C) The $k^{2}$ weighted $x(\mathrm{k})$ EXAFS spectra and their corresponding Fourier-transformations (D) The green lines represent the As-O and As-S bonding distances. 
Table 2 Summary of S, Fe and As K-edge XANES or EXAFS LCF fitting results

\begin{tabular}{|c|c|c|c|c|c|c|c|}
\hline \multirow{3}{*}{ Sample } & \multicolumn{7}{|c|}{ Mineralogical composition (\% mol S) } \\
\hline & \multicolumn{7}{|c|}{ XANES first-derivative } \\
\hline & pyrite & greigite & \multicolumn{2}{|c|}{$S_{0}$} & \multicolumn{2}{|c|}{$\mathrm{CaSO}_{4} \cdot 2 \mathrm{H}_{2} \mathrm{O}$} & $\mathbf{R}^{2}$ \\
\hline K2-17 & $14(2.6)$ & $70(4.1)$ & \multicolumn{2}{|c|}{$15(3)$} & \multicolumn{2}{|c|}{$1(0.4)$} & 0.091 \\
\hline K2-28 & $30(2.0)$ & - & \multicolumn{2}{|c|}{$61(2.9)$} & \multicolumn{2}{|c|}{$9(0.4)$} & 0.039 \\
\hline K1-71 & - & $93(1.2)$ & \multicolumn{2}{|c|}{$5(1.1)$} & \multicolumn{2}{|c|}{$2(0.3)$} & 0.058 \\
\hline \multirow{3}{*}{ Sample } & \multicolumn{7}{|c|}{ Mineralogical composition (\% mol As) } \\
\hline & \multicolumn{7}{|c|}{ XANES first-derivative } \\
\hline & realgar & arsenopyrite & \multicolumn{2}{|c|}{ As (III)-Fh } & \multicolumn{2}{|c|}{ As $(\mathbf{V})-\mathbf{F h}$} & $\mathbf{R}^{2}$ \\
\hline K2-17 & $47(6.9)$ & $0(4.2)$ & \multicolumn{2}{|c|}{$46(2.1)$} & \multicolumn{2}{|c|}{$7(1.5)$} & 0.0245 \\
\hline K2-28 & $8(5.0)$ & $61(6)$ & \multicolumn{2}{|c|}{$3.8(2.4)$} & \multicolumn{2}{|c|}{$27(1.7)$} & 0.0516 \\
\hline K1-71 & $41(0.5)$ & - & \multicolumn{2}{|c|}{$50(1.8)$} & \multicolumn{2}{|c|}{$10(1.1)$} & 0.0197 \\
\hline \multirow{3}{*}{ Sample } & \multicolumn{7}{|c|}{ Mineralogical composition (\% mol Fe) } \\
\hline & \multicolumn{7}{|c|}{ EXAFS } \\
\hline & pyrite & greigite & chlorite & illite & hematite & ferrihydrite & $\mathbf{R}^{2}$ \\
\hline K2-17 & $3(0.8)$ & $23(2.5)$ & $19(1.5)$ & $47(3.9)$ & $8(0.9)$ & - & 0.0469 \\
\hline K2-28 & $23(0.9)$ & - & $39(1.4)$ & $18(3.1)$ & - & $21(6.4)$ & 0.0445 \\
\hline K1-71 & - & $42(4.5)$ & $24(2.8)$ & $29(3.7)$ & $5(6.8)$ & - & 0.1581 \\
\hline
\end{tabular}

$299 \quad$ 3.4.2 Arsenic content and distribution in pyrite and greigite

300 Arsenic content of the pyrite and greigite grains was measured by EPMA and summarized in Table

301 3. Arsenic content in the pyrite grains ranged from $<90 \mathrm{mg} / \mathrm{kg}$ (detection limit of EPMA) to $302 \sim 11,000 \mathrm{mg} / \mathrm{kg}$ in both K2-17 and K2-28, respectively. Weak linear least squares fit was obtained 303 for the As:S atomic ratio in the pyrite grains $\left(\mathrm{R}^{2}=0.26\right)$ (Fig. 6). Framboidal rims with over-grown 304 pyrite crystallites contained more As than the framboid centers evidenced by two framboid 305 measurements (Supplementary Table S5). Arsenic distributions in pyrites were heterogeneous, 306 while the spatial distribution of As fluorescence intensities in the framboids showed a different 307 picture compared to $\mathrm{S}$ and Fe (Fig. 7). Ferrihydrite aggregates had average As content about 4,000 $308 \mathrm{mg} / \mathrm{kg}$, which was comparable with the average As content in pyrite measured using EPMA in 309 peat K2-28 (Supplementary Table S5). 
Table 3 Arsenic content in pyrite and greigite grains in the peat sediments based on the EPMA 311 analyses.

312

\begin{tabular}{|c|c|c|c|c|c|c|}
\hline Sample name & Mineral & $\begin{array}{c}\text { S/Fe (avg. } \\
\text { atomic \%) }\end{array}$ & $\begin{array}{c}\text { Min [As] } \\
(\mathbf{m g} / \mathbf{k g})\end{array}$ & $\begin{array}{c}\text { Max [As] } \\
(\mathbf{m g} / \mathbf{k g})\end{array}$ & $\begin{array}{c}\text { Average [As] } \pm \\
\text { SD (mg/kg) }\end{array}$ & $\mathbf{n}$ \\
\hline \multirow{2}{*}{ K2-17 } & pyrite & 2.00 & $<90$ & 11,040 & $5,205 \pm 5,155$ & 8 \\
\cline { 2 - 7 } & greigite & 1.24 & 460 & 1,380 & $1,024 \pm 341$ & 5 \\
\hline K2-28 & pyrite & 2.00 & 170 & 11,450 & $3,760 \pm 3,523$ & 22 \\
\hline K1-71 & greigite & 1.31 & 480 & 1,270 & $895 \pm 321$ & 8 \\
\hline
\end{tabular}

In contrast to pyrite, arsenic had a relatively homogeneous distribution in the greigite grains ranging from 500 to $1,400 \mathrm{mg} / \mathrm{kg}$ (Table 3). Spatial As distribution was similar to the distribution of $\mathrm{S}$ and Fe fluorescence intensities (Fig. 7). Unfortunately, the result obtained from EPMA analysis may slightly underestimate the As content in the pyrite and greigite, while the total weight percent of $\mathrm{S}$ and $\mathrm{Fe}$ is $80 \%$ and $93 \%$ (on average) for greigite and pyrite, respectively (Supplementary Table S5). Except Fe (oxyhydr)oxides and sulfides, Fe-bearing phyllosilicates, especially clay minerals such as illite and chlorite, can also incorporate/adsorb As (Fakhreddine et al., 2015). However, our results showed that the influence from phyllosilicates was limited, as shown by the $\mathrm{S} / \mathrm{Fe}$ atom ratios of pyrite and greigite which were similar to the stoichiometric ratios (Table 2). Furthermore, the distribution patterns of elements including $\mathrm{Si}, \mathrm{Mg}$ and $\mathrm{K}$, which are the main components of phyllosilicates, do not show any correlations with As distributions (Supplementary Fig. S4).

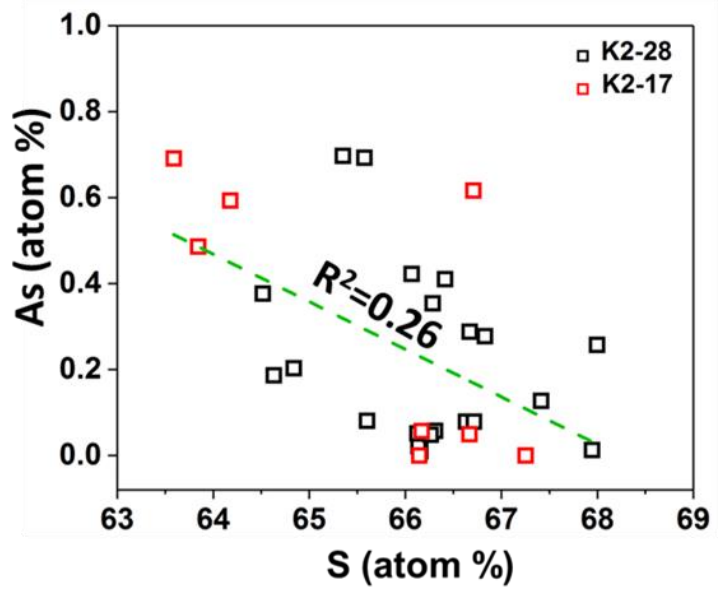


Fig. 6 Sulfur $v s$ As atomic ratio measured by EPMA in peat samples.
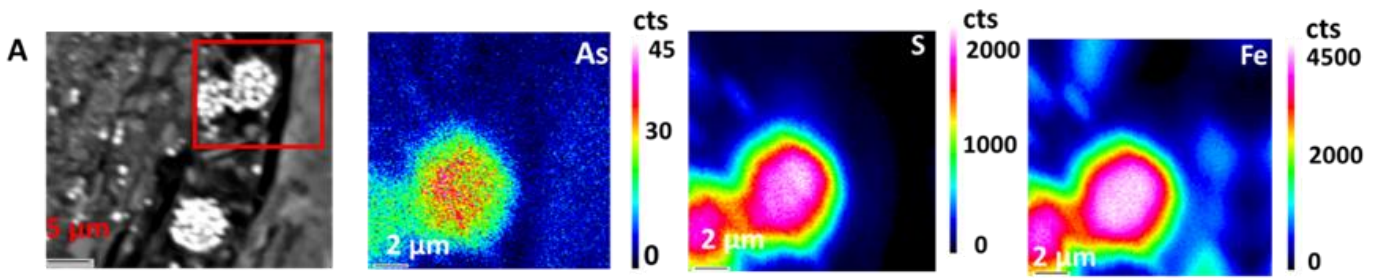

B
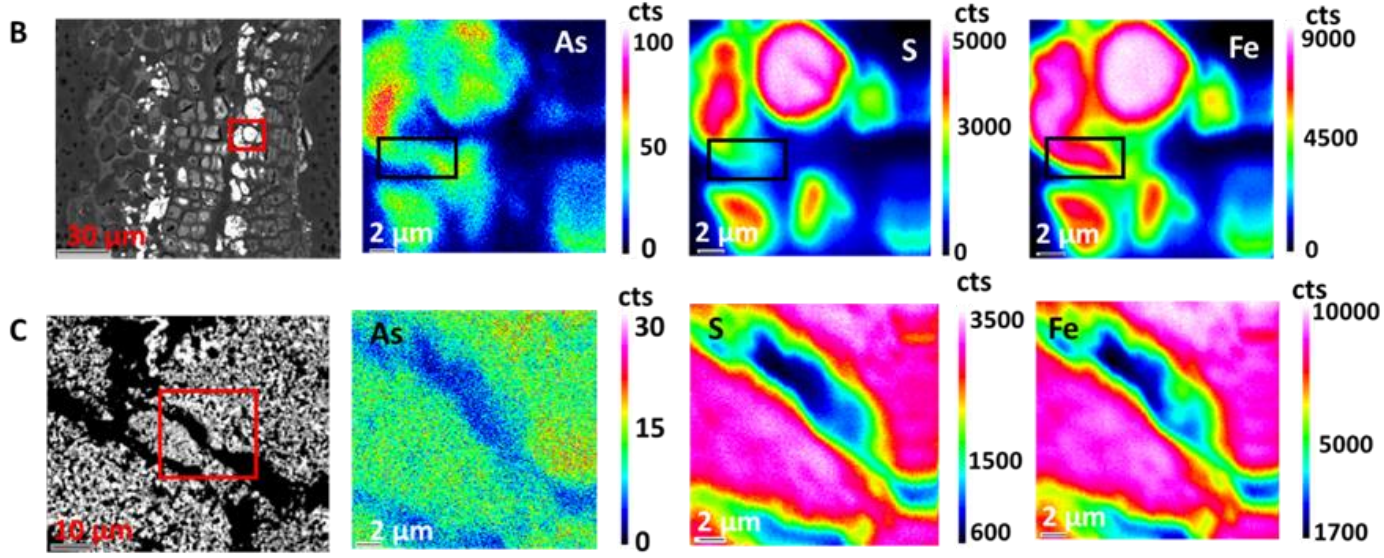

Fig. 7 Elemental mapping images of S, Fe and As elements obtained by EPMA, mapping area is indicated by red rectangle. (A) Map of framboidal pyrites area in sample K2-17. (B) Map of pyrites area in sample K2-28 which has nucleated in plant tissues, mapping area is indicated by a black rectangle corresponding to ferrihydrite (C) Map of greigite area in sample K1-71.

\section{Discussion}

\subsection{Diagenetic formation of Fe sulfides}

The main minerals in the peat sediments include quartz, feldspar, carbonates and clay minerals, which has similar composition with the other sediments in the cores (Wang et al., 2019 a). This suggests that the peat sediments have the same provenance with other sediments. Furthermore, the

337 Fe sulfides found in the peat are likely of authigenic origin which can only be transported via small 338 scales because they are susceptible to oxidation (Lowers et al., 2007). Therefore, the Fe sulfides 339 found in the peat sediments were formed in situ. 
340 Two proposed mechanisms, which are still under debate, can explain this pyrite formation via 341 mackinawite (nominally "FeS") transformation, either by "FeS" reacting with 342 polysulfides/elemental sulfur $\left(\mathrm{S}_{0}\right)$ (Eq. 1) or "FeS" reacting with $\mathrm{H}_{2} \mathrm{~S}($ Eq. 2) (Benning et al., 2000):

$$
\mathrm{FeS}+\mathrm{S}_{0} \rightarrow \mathrm{FeS}_{2} \text { or } \mathrm{FeS}+S_{n}^{2-} \rightarrow \mathrm{FeS}_{2}+S_{n-1}^{2-}[1]
$$

$$
\mathrm{FeS}+\mathrm{H}_{2} \mathrm{~S} \rightarrow \mathrm{FeS}_{2}+\mathrm{H}_{2}[2]
$$

Reaction between $S_{0}$ precipitates and mackinawite [eq. 1] is most likely the dominant mechanism of pyrite formation since large proportions of $S_{0}(60 \%$ of total $S)$ are detected together with pyrite.

$347 \mathrm{~S}_{0}$ could have formed though sulfide oxidation coupled with Fe(III) reduction in such Fe-enriched sediments. Formation of pyrite via the polysulfides $/ \mathrm{S}_{0}$ pathway is typical in the oxic-anoxic transition zone of sediments (Berner, 1970; Neumann et al., 2005; Koeksoy et al., 2019), In the 350 early diagenetic stage, the degradation of organic matter in the saturated water provides electrons 351 for the reductive dissolution of $\mathrm{SO}_{4}{ }^{2-}$ and $\mathrm{Fe}(\mathrm{III})$. This is followed by the subsequent precipitation 352 of "FeS" upon saturation of $\mathrm{Fe}(\mathrm{II})$ and $\mathrm{S}(-\mathrm{II})$, and thereby resulting in the formation of pyrite via 353 "FeS" reacting with $\mathrm{S}_{0}$. The inhomogeneous framboid and euhedral pyrite sizes distribution could 354 indicate unsteady geochemical conditions (Wilkin et al., 1996, 1997). The overgrowth of framboid, 355 as well as the filled texture, is usually related to the secondary diagenetic growth of pyrite after 356 formation in the surface water-sediment interface during early diagenetic process (Wilkin and 357 Barnes, 1997), and the growth rate is limited by the sulfide supply, which can be constrained by 358 labile organic matter in the sulfidic conditions or availability of $\mathrm{SO}_{4}{ }^{2-}$ in porewater.

359 Greigite is a metastable iron sulfide mineral that is suggested to form as an intermediate during the 360 oxidative transformation of mackinawite to pyrite (Vasiliev et al., 2008; Rickard and Luther, 2007;

361 Pickard et al., 2017). However, the formation pathway and preservation mechanisms of this 
362 metastable mineral phase are still not fully understood, even though it has been increasingly

363 recognized as an important sedimentary mineral. There have been few studies that show

364 transformation of mackinawite to pyrite can be inhibited in natural sediments settings (Wilkin and

365 Ford, 2006; Holmkvist et al., 2011; Burton et al., 2011). This is the case in one of the peats (K1-

366 71) from Hetao Basin, wherein greigite is shown in the sample. In comparison with pyrite-

367 dominant peats, greigite-dominant peats have less organic matter and sulfur content, whereas the

368 Fe content is comparable. This can be attributed to the likely precipitation of mackinawite which

369 could remove sulfide from the pore water. The excess $\mathrm{Fe}^{2+}$ could exhaust sulfide, therefore,

370 preventing polysulfide/ $\mathrm{S}_{0}$ formation and the subsequent transformation of greigite to pyrite. The

371 lower sulfide flux in greigite-dominant layers compared to pyrite-dominant layers can be related

372 to the limited labile organic carbon content or lower $\mathrm{SO}_{4}{ }^{2-}$ concentration. This further emphasizes

373 the importance of polysulfides/S $\mathrm{S}_{0}$ for the transformation of metastable iron sulfide precursors to

374 pyrite under anoxic conditions in natural sediments. However, formation of greigite from a

375 mackinawite precursor also requires an oxidant (Wilkin and Barnes, 1997; Schippers and

376 Jørgensen, 2002; Hunger and Benning 2007). In the surface water-sediment interface, the

377 penetration of oxidants such as $\mathrm{O}_{2}$ and $\mathrm{NO}_{3}{ }^{-}$probably favor the transformation of FeS into greigite

378 while polysulfides $/ \mathrm{S}_{0}$ is limited.

379 Phyllosilicates and decaying plant tissues provide the ideal micro-environments for pyrite/greigite 380 nucleation and growth. Reactive $\mathrm{Fe}^{2+}$ provided by Fe-rich phyllosilicates via chemical or microbial 381 reduction can induce supersaturation and precipitation of mackinawite on the silicates surface and 382 subsequent transformation into pyrite/greigite. Some sulfate reducing bacteria such as 383 Desulfovibrio sp. can reduce organic sulfur species into inorganic sulfides, which can also drive 384 mackinawite formation in tissues (Alschuler et al., 1983). In addition, plant tissues can provide 
active surface area and decrease the oversaturation required for Fe sulfide nucleation (Rickard et al., 2007). Since organic sulfur is not detected in the S K-edge XANES spectra $(<5 \%)$ of the peat samples, it suggests that microbial reduction of organic sulfur could have provided the inorganic sulfide needed for the formation of the mackinawite precursor. This result is contrary with previous study which has shown that inorganic sulfide is coupled with organic carbon as thiol functional groups, which in turn can sequester metalloids such as As (Langer et al., 2012; Wang et al., 2018). This might be a result of the differences in the ratio of reactive Fe to sulfur. The high abundance of reactive iron can remove inorganic sulfide in such Fe-rich sediments, thereby inhibiting transformation of inorganic sulfide to thiol functional groups.

\subsection{Arsenic incorporation into Fe sulfides}

Although relatively weakly correlated, the liner relationship between the $\mathrm{S}$ and As atomic ratios suggests that As possibly substitutes for $\mathrm{S}$ in the crystal structure of pyrite to form arsenian pyrite. The incorporation of As into pyrites is further evidenced by the As K-edge derivative XANES fits. In the pyrite-dominant peat sediments, our XANES data showed that approximate $60 \%$ of As exists as As(-I). The pyrite sequestration mechanism for As is consistent with previous studies of pyritic As sequestration mechanisms in natural sediments at low temperatures (Savage et al., 2000; Lowers et al., 2007). Arsenic content in the pyrite particles is between $<90 \mathrm{mg} / \mathrm{kg}$ to $11,000 \mathrm{mg} / \mathrm{kg}$ with an average value around 5,000 $\mathrm{mg} / \mathrm{kg}$, showing that pyrite plays an important role for As sequestration in peat sediments. The similar maximum pyrite As concentrations in sediments from Bangladesh and the Hetao Basin suggests that the maximum As content incorporated into pyrite grains is around 1 wt.\% under typical aquifer conditions (Lowers et al.,2007). The heterogeneous distributions of As in pyrite can be related to pyrite growth rates as well as contact time with porewater. The slightly higher As concentrations found in the framboid over-growth rims as well 
as massive pyrites could be related to longer crystallization time, leading to enhanced As incorporation from the surrounding pore water into the pyrite structure (Lowers et al., 2007; Neumann et al., 2013). Moreover, the resulting arsenian pyrites are still expected to be able to adsorb pore water As in the form of $\mathrm{As}(\mathrm{III})$ or $\mathrm{As}(\mathrm{V})$ species, or form As-S precipitates (Bostick

412 and Fendorf, 2003; Qiu et al., 2018). This is consistent with our field observation that As 413 concentration is relatively low in the groundwater with blackish-suspended particles, which likely 414 corresponds to pyrite.

415 To our knowledge, adsorption and/or incorporation of As by greigite in both lab-scale batch 416 reactions and in engineered and natural aquatic environments are still poorly investigated. The 417 average As content of greigite particles as measured by EPMA, when multiplied by the amount of 418 greigite determined in our samples, is comparable to the fraction of As bound in As sulfide 419 (Supplementary text 5). Therefore, our results show that greigite is an important sink for As in 420 the peat sediments with relatively lower $\mathrm{S}$ and organic carbon content and is primarily coordinated 421 to sulfur within these particles, which is analogous to realgar evidenced by As K-edge XANES 422 fitting. During greigite formation, oxidation of mackinawite coupled with As(III) species reduction 423 may cause the surface precipitation of greigite and realgar. The findings in our study is consistent 424 with the model predictions by Gallegos et al., (2008), where they argued that the formation of 425 greigite is thermodynamically favorable by the reaction of As(III) species and mackinawite. 426 Realgar and orpiment are also potential As carrier phases in the sulfidic sediments (O'Day et al., 4272004 a). However, greigite formation also uses up the available sulfide, therefore limiting As 428 sulfides (i.e., realgar, orpiment) formation. Furthermore, it can also be constrained by relatively 429 lower As concentrations in the pore water since As sulfide formation needs high porewater As 430 concentration (O’Day et al., 2004 b; Langner et al., 2012). 


\subsection{Significance of peat sediments for As mobilization process in aquifers}

432 Our study clearly shows that Fe sulfides including greigite and pyrite formed in peat lenses could 433 be important As sinks in contaminated aquifers. Sulfide flux controls Fe sulfides formation, while 434 the sulfide flux would be in turn controlled either by labile organic matter in peat or $\mathrm{SO}_{4}{ }^{2-}$ flux in 435 the $\mathrm{SO}_{4}{ }^{2-}$ limited groundwater (Lowers et al., 2007). In comparison to Fe (oxyhydr)oxides, greigite 436 and pyrite are more thermodynamically stable under these sub-oxic conditions. Therefore, As

437 release caused by reductive dissolution of iron (oxyhydr)oxides would not happen in the 438 groundwater, and competitive adsorption between dissolved phosphate and silica and As on the 439 reactive surfaces of Fe sulfides also cannot occur.

440 However, oxidation of arsenian pyrite to ferrihydrite-As(V) species can be ongoing process under 441 slightly oxic conditions, as we have observed in the peat layer K2-28 (Fig. 1). Transferring As 442 from surface or structure of arsenian pyrite onto ferrihydrite can temporarily retards the As release, 443 which is supported by the similar average As content found in the ferrihydrite and pyrite as well 444 as low As concentrations $(<10 \mu \mathrm{g} / \mathrm{L})$ in the groundwater (Fig. 1). However, ferrihydrite can 445 potentially be reduced under disturbed groundwater redox conditions, which may cause elevated 446 As concentration in the groundwater, since Fe sulfides re-formation is constrained by labile 447 organic carbon. Groundwater redox conditions in draining delta or basins of South and Southeast 448 Asia frequently experience anthropogenic perturbations, as well as seasonal fluctuations (Harvey 449 et al., 2002; Fendorf et al., 2010), making Fe sulfides as an As source with respect to potential As 450 remobilization. In recent years, in situ formation of Fe sulfides is suggested to remediate 451 groundwater As pollution (Keimowitz et al., 2007; Pi et al., 2017). However, it is not suggested to 452 apply it in such naturally unmanaged aquifer. 
453 Previous studies also suggested that reactive organic carbon can be transported to other area by

454 groundwater flow, therefore stimulating As release following by Fe (oxyhydr)oxides and As(V)

455 species reduction (McArthur et al., 2001,2004; Fendorf et al., 2010), but there is no solid evidence

456 to prove that. Our study indicates that the labile organic matter buried in the peat sediments from

457 aquifer can already be exhausted by early diagenetic $\mathrm{Fe}$ and $\mathrm{S}$ reduction. Our findings are

458 consistent with the results found by Stuckey et al. (2015b), wherein organic matter leached from

459 Mangrove deposits from Mekong delta cannot be able to simulate Fe (oxyhydr)oxides reduction.

460 5. Summary and Conclusion

461 Detrital peat formed from swamps or excessive flood debris is common in the As-contaminated

462 aquifer of South and South-east Asia. To investigate the mineral diagenesis and sequestration

463 behavior for As in these organic carbon-rich deposits, three peat lenses were retrieved from two

464 cores with depths up to $80 \mathrm{~m}$ in the Hetao Basin.

465 Simultaneous microbial reduction of organic and inorganic sulfate favored Fe sulfide nucleation

466 in the decaying plant tissues and phyllosilicates. Greigite and pyrite formed in surface water-

467 sediment interface as the diagenetic minerals were stable in peat sediments under anoxic conditions.

468 Excessive $\mathrm{Fe}(\mathrm{II})$ compared to sulfide due to lower sulfide flux potentially inhibited pyrite

469 formation in the sulfidic porewater.

470 Peat sediments show a stable sink for As under steady anoxic conditions with As concentrations

471 up to $250 \mathrm{mg} / \mathrm{kg}$. Pyrite crystallites can have As content up to $11,000 \mathrm{mg} / \mathrm{kg}$, with a majority of

472 the As(-I) substitutes for S(-I) in the pyrite structure. Arsenic content in the greigite grains is

473 relatively homogeneous, ranging from $\sim 500$ to $\sim 1,400 \mathrm{mg} / \mathrm{kg}$. We suggest that As forms distinct

474 As sulfide precipitates in greigite-rich peats, as indicated by our As K-edge XAS data. 
475 Anthropogenic perturbations and seasonal fluctuation of groundwater tables can largely change 476 the groundwater redox conditions, for example, recharge of surface water caused by groundwater 477 extraction infiltrates $\mathrm{O}_{2}$ into groundwater. The increase of redox potential can induce Fe sulfides

478 (e.g. pyrite and greigite) transfer to Fe (oxyhydr)oxides and temporarily retard As release into 479 groundwater. However, reductive dissolution may in turn release As from the newly-formed iron 480 (oxyhydr)oxide phase, as there is insufficient organic matter for transformation of these phases to 481 Fe sulfide minerals and sequestration of As.

\section{Acknowledgement}

$483 \mathrm{XRF}, \mathrm{XRD}, \mathrm{CSA}$, as well as HR-ICP-MS and IR-MS analysis were performed at KIT. The authors 484 give thanks to Beate Oetzel, Claudia Moessner and Gesine Preuss for their technical assistance. 485 We thank Ralf Steininger for his support during the collection of Fe, As and S K-edge XAS data 486 at ANKA. The authors also acknowledge the CUGB group for their assistance during the field trip 487 to the Hetao Basin and travel funding provided from the GRACE graduate program at KIT. We 488 are also grateful for the advice from Elisabeth Eiche for $\mathrm{C}$ isotope analysis and Nicolas Börsig for 489 XAS fitting analysis. The As K-edge XAS data of K2-28was collected at the BM23 beamline at 490 ESRF (experiment no. EV-338), and the authors thank Sakura Pascarelli for assistance during 491 beamtime. We further acknowledge the financial support from the Helmholtz Recruiting Initiative 492 (award number I-044-16-01) awarded to L.G.B. J.P.H.P. and A.N.T. are supported by the 493 European Union’s Horizon 2020 Marie Skłodowska-Curie Innovative Training Network Grant No. 494 675219, and H.Y.W is supported by Chinese scholarship Council Grant No. 201606400055. 495 Finally, we are grateful for the insightful comments from EIC Prof. Jeffrey Catalano, AE Prof. 496 Caroline Peacock and three anonymous reviewers.

497 Reference 
Altschuler, Z.S., Schnepfe, M.M., Silber, C.C., Simon, F.O. (1983). Sulfur diagenesis in 499 Everglades peat and origin of pyrite in coal. Science, 221(4607), 221-227.

500 Anawar, H. M., Akai, J., Komaki, K., Terao, H., Yoshioka, T., Ishizuka, T., Safiullah S., Kato, K. 501 (2003). Geochemical occurrence of arsenic in groundwater of Bangladesh: sources and mobilization processes. J. Geochem. Explor, 77(2-3), 109-131.

503 Benning, L. G., Wilkin, R. T., Barnes, H. L. (2000). Reaction pathways in the Fe-S system below $504100{ }^{\circ} \mathrm{C}$. Chem. Geol, 167(1-2), 25-51.

505

506

507

508

509

510

511

512

513

514

515

516

517

518

519

520

521

522

523

524

525

526

527

528

529

530

531

Berner, R.A., (1970). Sedimentary pyrite formation. Am. J. Sci, 268(1), 1-23.

Blanchard, M., Alfredsson, M., Brodholt, J., Wright, K., Catlow, C. R. A. (2007). Arsenic incorporation into FeS2 pyrite and its influence on dissolution: a DFT study. Geochim. Cosmochim. Acta, 71(3), 624-630.

Bostick, B.C., Fendorf, S. (2003). Arsenite sorption on troilite (FeS) and pyrite (FeS2). Geochim. Cosmochim. Acta, 67(5), 909-921.

Burton, E. D., Johnston, S. G., Bush, R. T. (2011). Microbial sulfidogenesis in ferrihydrite-rich environments: Effects on iron mineralogy and arsenic mobility. Geochim. Cosmochim. Acta, 75(11), 3072-3087.

Cai, M., Ye, P., Yang, X., Li, C. (2019). Vegetation and climate change in the Hetao Basin (Northern China) during the last interglacial-glacial cycle. J. Asian. Earth. Sci, 171, 1-8.

Chen, C., Kukkadapu, R.K., Lazareva, O., Sparks, D.L. (2017). Solid-phase Fe speciation along the vertical redox gradients in floodplains using XAS and Mössbauer spectroscopies. Environ. Sci. Technol, 51(14), 7903-7912.

Deng, Y., Wang, Y., Ma, T. (2009). Isotope and minor element geochemistry of high arsenic groundwater from Hangjinhouqi, the Hetao Plain, Inner Mongolia. Appl. Geochem, 24(4), 587599.

Fakhreddine S, Dittmar J, Phipps D, et al. (2015). Geochemical Triggers of Arsenic Mobilization during Managed Aquifer Recharge. Environ. Sci. Technol, 49(13):7802-7809.

Fendorf, S., Michael, H. A., van Geen, A. (2010). Spatial and temporal variations of groundwater arsenic in South and Southeast Asia. Science, 328(5982), 1123-1127.

Gallegos, T. J., Han, Y. S., Hayes, K. F. (2008). Model predictions of realgar precipitation by reaction of As (III) with synthetic mackinawite under anoxic conditions. Environ. Sci. Technol, 42(24), 9338-9343.

Guo, H., Liu, C., Lu, H., Wanty, R. B., Wang, J., Zhou, Y. (2013). Pathways of coupled arsenic and iron cycling in high arsenic groundwater of the Hetao basin, Inner Mongolia, China: An iron isotope approach. Geochim. Cosmochim. Acta, 112, 130-145. 
Harvey, C. F., Swartz, C. H., Badruzzaman, A. B. M., Keon-Blute, N., Yu, W., Ali, M. A., Jay J., Beckie R., Niedan V., Brabander D., Oates P. M., Ashfaque K. N., Islam S., Hemond H. F., Ahmed M. F. (2002). Arsenic mobility and groundwater extraction in Bangladesh. Sci., 298(5598), 16021606.

Holmkvist, L., Ferdelman T. G., Jørgensen B. B. (2011). A cryptic sulfur cycle driven by iron in the methane zone of marine sediment (Aarhus Bay, Denmark). Geochim. Cosmochim. Acta, 35813599.

Hunger, S., Benning, L. G. (2007). Greigite: a true intermediate on the polysulfide pathway to pyrite. Geochem. Trans, $\mathbf{8}(\mathbf{1}), 1$.

Islam, F. S., Gault, A. G., Boothman, C., Polya, D. A., Charnock, J. M., Chatterjee, D., Lloyd, J. R. (2004). Role of metal-reducing bacteria in arsenic release from Bengal delta sediments. Nature, 430(6995), 68.

Jia, L., Zhang, X., Ye, P., Zhao, X., He, Z., He, X., Zhou, Q., Li, J., Ye, M., Wang, Z., Meng, J. (2016). Development of the alluvial and lacustrine terraces on the northern margin of the Hetao Basin, Inner Mongolia, China: Implications for the evolution of the Yellow River in the Hetao area since the late Pleistocene. Geomorphol, 263, 87-98.

Keimowitz, A. R., Mailloux, B. J., Cole, P., Stute, M., Simpson, H. J., Chillrud, S. N. (2007). Laboratory investigations of enhanced sulfate reduction as a groundwater arsenic remediation strategy. Environ. Sci. \& technol, 41(19), 6718-6724.

Kirk, M. F., Roden, E. E., Crossey, L. J., Brealey, A. J., Spilde, M. N. (2010). Experimental analysis of arsenic precipitation during microbial sulfate and iron reduction in model aquifer sediment reactors. Geochim. Cosmochim. Acta, 74(9), 2538-2555.

Klementiev, K. V. (2012). XAFSmass. A program for calculating the mass of XAFS samples.

Knappová, M., Drahota, P., Falteisek, L., Culka, A., Penížek, V., Trubač, J., Mihaljevič M., Matoušek, T. (2019). Microbial sulfidogenesis of arsenic in naturally contaminated wetland soil. Geochim. Cosmochim. Acta, 267, 33-50.

Kocar, B.D., Borch, T., Fendorf, S. (2010). Arsenic repartitioning during biogenic sulfidization and transformation of ferrihydrite. Geochim. Cosmochim. Acta, 74(3), 980-994.

Koeksoy, E., Sundman, A., Byrne, J.M., Lohmayer, R., Planer-Friedrich, B., Halevy, I., Konhauser, K.O., Kappler, A. (2019). Formation of green rust and elemental sulfur in an analogue for oxygenated ferro-euxinic transition zones of Precambrian oceans. Geology, 47(3), 211-214.

Langner, P., Mikutta, C., Kretzschmar, R. (2012). Arsenic sequestration by organic sulphur in peat. Nat. Geosci, 5(1), 66.

Langner, P., Mikutta, C., Suess, E., Marcus, M. A., Kretzschmar, R. (2013). Spatial distribution and speciation of arsenic in peat studied with microfocused X-ray fluorescence spectrometry and X-ray absorption spectroscopy. Environ. Sci. Technol, 47(17), 9706-9714. 
Le, P. P., Blanchard, M., Brest, J., Boulliard, J. C., Ikogou, M., Stetten, L., Wang, S., Landort G., Morin, G. (2017). Arsenic Incorporation in Pyrite at Ambient Temperature at Both Tetrahedral SI and Octahedral FeII Sites: Evidence from EXAFS-DFT Analysis. Environ. Sci. Technol, 51(1), $150-158$.

Lowers, H. A., Breit, G. N., Foster, A. L., Whitney, J., Yount, J., Uddin, M. N., Muneem, A. A. (2007). Arsenic incorporation into authigenic pyrite, Bengal Basin sediment, Bangladesh. Geochim. Cosmochim. Acta, 71(11), 2699-2717.

Manceau, A. and Nagy, K.L. (2012). Quantitative analysis of sulfur functional groups in natural organic matter by XANES spectroscopy. Geochim. Cosmochim. Acta, 99, 206-223.

McArthur, J. M., Banerjee, D. M., Hudson-Edwards, K. A., Mishra, R., Purohit, R., Ravenscroft, P., Cronin A., Howarth R. J.,Chatterjee A, Talukder T., Lowry, D., Houghton S., Chadha D.K (2004). Natural organic matter in sedimentary basins and its relation to arsenic in anoxic ground water: the example of West Bengal and its worldwide implications. Appl Geochem, 19(8), 12551293.

McArthur, J. M., Ravenscroft, P., Safiulla, S., Thirlwall, M. F. (2001). Arsenic in groundwater: testing pollution mechanisms for sedimentary aquifers in Bangladesh. Water Resour. Res, 37(1), 109-117.

Naafs, B. D. A., Inglis, G. N., Blewett, J., McClymont E. L., Lauretano V., Xie, S., Evershed, R. P., Pancost, R. D. (2019). The potential of biomarker proxies to trace climate, vegetation, and biogeochemical processes in peat: A review. Glob Planet Change, 179, 57-79.

Neumann, T., Rausch, N., Leipe, T., Dellwig, O., Berner, Z., Böttcher, M.E. (2005). Intense pyrite formation under low-sulfate conditions in the Achterwasser lagoon, SW Baltic Sea. Geochim. Cosmochim. Acta, 69(14), 3619-3630.

Nickson, R., McArthur, J., Burgess, W., Ahmed, K. M., Ravenscroft, P., Rahmanñ, M. (1998). Arsenic poisoning of Bangladesh groundwater. Nature, 395(6700), 338.

O’Day, P.A., Rivera Jr, N., Root, R., Carroll, S.A., (2004 a). X-ray absorption spectroscopic study of Fe reference compounds for the analysis of natural sediments. Am. Mineral., 89(4), 572-585.

O'Day, P. A., Vlassopoulos, D., Root, R., Rivera, N. (2004 b). The influence of sulfur and iron on dissolved arsenic concentrations in the shallow subsurface under changing redox conditions. Proc. Natl. Acad. Sci., 101(38), 13703-13708.

Pannalal, S.J., Crowe, S.A., Cioppa, M.T., Symons, D.T., Sturm, A. and Fowle, D.A. (2005). Room-temperature magnetic properties of ferrihydrite: A potential magnetic remanence carrier? Earth Planet. Sci. Lett, 236(3-4), 856-870.

Pi, K., Wang, Y., Xie, X., Ma, T., Liu, Y., Su, C., Zhu, Y., Wang, Z. (2017). Remediation of arsenic-contaminated groundwater by in-situ stimulating biogenic precipitation of iron sulfides. Water Res., 109, 337-346. 
Pickard D., Mussmann M., Steadman J. A. (2017). Sedimentary Sulfides. Elements, 13(2), 117122.

Qiu, G., Gao, T., Hong, J., Luo, Y., Liu, L., Tan, W., Liu, F. (2018). Mechanisms of interaction between arsenian pyrite and aqueous arsenite under anoxic and oxic conditions. Geochim. Cosmochim. Acta, 228, 205-219.

Rancourt, D.G., Ping, J.Y. (1991). Voigt-based methods for arbitrary-shape static hyperfine parameter distributions in Mössbauer spectroscopy. Nucl. Instrum. Methods Phys. Res: Beam Interactions with Materials and Atoms, 58(1), 85-97.

Ravel, B. and Newville, M.A.T.H.E.N.A. (2005). ATHENA, ARTEMIS, HEPHAESTUS: data analysis for X-ray absorption spectroscopy using IFEFFIT. J. Synchrotron Radiat, 12(4), 537-541.

Rickard D. and Luther G. W (2007). Chemistry of Iron Sulfides. Chem. Rev, 107(2), 514-562.

Rickard, D., Grimes, S., Butler, I., Oldroyd, A. and Davies, K.L. (2007). Botanical constraints on pyrite formation. Chem. Geol, 236(3-4), 228-246.

Savage, K.S., Tingle, T.N., O’Day, P.A., Waychunas, G.A. and Bird, D.K. (2000). Arsenic speciation in pyrite and secondary weathering phases, Mother Lode gold district, Tuolumne County, California. Appl. Geochem, 15(8), 1219-1244.

Schippers, A., Jørgensen, B.B. (2002). Biogeochemistry of pyrite and iron sulfide oxidation in marine sediments. Geochim. Cosmochim. Acta, 66(1), 85-92.

Smith, P.G., Koch, I., Gordon, R.A., Mandoli, D.F., Chapman, B.D., Reimer, K.J. (2005). X-ray absorption near-edge structure analysis of arsenic species for application to biological environmental samples. Environ. Sci. Technol, 39(1), 248-254.

Smith, R. L., Kent, D. B., Repert, D. A., Böhlke, J. K. (2017). Anoxic nitrate reduction coupled with iron oxidation and attenuation of dissolved arsenic and phosphate in a sand and gravel aquifer. Geochim. Cosmochim. Acta, 196, 102-120.

Stuckey, J. W., Schaefer, M. V., Benner, S. G., Fendorf, S. (2015 a). Reactivity and speciation of mineral-associated arsenic in seasonal and permanent wetlands of the Mekong Delta. Geochim. Cosmochim. Acta, 171, 143-155.

Stuckey, J. W., Schaefer, M. V., Kocar, B. D., Dittmar, J., Pacheco, J. L., Benner, S. G., Fendorf, S. (2015 b). Peat formation concentrates arsenic within sediment deposits of the Mekong Delta. Geochim. Cosmochim. Acta, 149, 190-205.

Thomas-Arrigo, L.K., Mikutta, C., Byrne, J., Barmettler, K., Kappler, A., Kretzschmar, R. (2014). Iron and arsenic speciation and distribution in organic flocs from streambeds of an arsenicenriched peatland. Environ. Sci. Technol, 48(22), 13218-13228.

Upadhyaya, G., Jackson, J., Clancy, T. M., Hyun, S. P., Brown, J., Hayes, K. F., Raskin, L. (2010). Simultaneous removal of nitrate and arsenic from drinking water sources utilizing a fixed-bed bioreactor system. Water Res, 44(17), 4958-4969. 
640 Vandenberghe, R.E., De Grave, E., De Bakker, P.M.A., Krs, M. and Hus, J.J. (1992). Mössbauer 641 effect study of natural greigite. Hyperfine Interact, 68(1-4), 319-322.

642 Vasiliev, I., Franke, C., Meeldijk, J. D., Dekkers, M. J., Langereis, C. G., Krijgsman, W. (2008). 643 Putative greigite magnetofossils from the Pliocene epoch. Nat. Geosci, 1(11), 782.

644 Wang, H. Y., Guo, H. M., Xiu, W., Bauer, J., Sun, G. X., Tang, X. H., Norra, S. (2019 a). 645 Indications that weathering of evaporite minerals affects groundwater salinity and As mobilization 646 in aquifers of the northwestern Hetao Basin, China. Appl. Geochem, 109, 104416.

647 Wang, X., Zhu, M., Koopal, L.K., Li, W., Xu, W., Liu, F., Zhang, J., Liu, Q., Feng, X., Sparks, 648 D.L. (2016). Effects of crystallite size on the structure and magnetism of ferrihydrite. Environ. Sci.: 649 Nano, 3(1), 190-202.

650 Wang, Y., Le Pape, P., Morin, G., Asta, M. P., King, G., Bártová, B., Suvorova, E., Frutschi, M., 651 lkogou, M., Cong Pham V.H., Le Vo, P., Herman, F., Charlet, L, Bernier-Latmani B., (2018). 652 Arsenic speciation in Mekong Delta sediments depends on their depositional environment. 653 Environ. Sci. Technol, 52(6), 3431-3439.

654 Wang, Y., Pi, K., Fendorf, S., Deng, Y., Xie, X. (2019 b). Sedimentogenesis and 655 hydrobiogeochemistry of high arsenic Late Pleistocene-Holocene aquifer systems. Earth-Sci. Rev, 656 189, 79-98.

657 Wilkin, R. T., Arthur, M. A., Dean, W. E. (1997). History of water-column anoxia in the Black 658 Sea indicated by pyrite framboid size distributions. Earth Planet. Sci. Lett, 148(3-4), 517-525.

659 Wilkin, R. T., Barnes, H. L., Brantley, S. L. (1996). The size distribution of framboidal pyrite in 660 modern sediments: an indicator of redox conditions. Geochim. Cosmochim. Acta, 60(20), 38976613912.

662 Wilkin, R. T., Ford, R. G. (2006). Arsenic solid-phase partitioning in reducing sediments of a 663 contaminated wetland. Chem. Geol, 228(1-3), 156-174.

664 Wilkin, R.T. and Barnes, H.L. (1997). Formation processes of framboidal pyrite. Geochim. 665 Cosmochim. Acta, 61(2), 323-339.

666 Winkel, L., Berg, M., Amini, M., Hug, S. J., Johnson, C. A. (2008). Predicting groundwater arsenic 667 contamination in Southeast Asia from surface parameters. Nat. Geosci, 1(8), 536.

668 Wolthers, M., Charlet, L., van Der Weijden, C.H., Van der Linde, P.R., Rickard, D. (2005). 669 Arsenic mobility in the ambient sulfidic environment: Sorption of arsenic (V) and arsenic (III) 670 onto disordered mackinawite. Geochim. Cosmochim. Acta, 69(14), 3483-3492.

671 Zhang, Z., Guo, H. M., Liu, S., Weng, H. C., Han, S. B., Gao, Z. P. (2020). Mechanisms of 672 groundwater arsenic variations induced by extraction in the western Hetao Basin, Inner Mongolia, 673 China. J. Hydrol, 583(124599), 1-13.

674 Zhu, Y. G., Xue, X. M., Kappler, A., Rosen, B. P., Meharg, A. A. (2017). Linking genes to 675 microbial biogeochemical cycling: lessons from arsenic. Environ. Sci. Technol, 51(13), 7326-7339. 